\title{
Study of the Nature and Structure of Corporate Culture with Neural Network Models
}

\author{
Sergiy V. Kovalevskyy ${ }^{1}$, Ludmila V. Kosheva ${ }^{2}$ \\ ${ }^{1}$ Donbas State Engineering Academy, Faculty of integrated technology and equipment, Kramatorsk, Ukraine \\ ${ }^{2}$ Donbas State Engineering Academy, Faculty of Economics and Management, Kramatorsk, Ukraine
}

\section{Email address:}

kovalevskii@i.ua (S. V. Kovalevskyy),kosheva@i.ua (L. V. Kosheva)

\section{To cite this article:}

Sergiy V. Kovalevskyy, Ludmila V. Kosheva. Study of the Nature and Structure of Corporate Culture with Neural Network Models. American Journal of Neural Networks and Applications. Vol. 1, No. 1, 2015, pp. 11-22. doi: 10.11648/j.ajnna.20150101.12

\begin{abstract}
The article contains the new materials reflecting application of neural network models in designing of innovative processes in pedagogic. Such approach, according to authors' point of view, is actual because it is very important to provide quantitative estimations along with quality standards for management of pedagogical processes. They allow to reveal tendencies of innovative pedagogical approaches in education of new generation of young men, but also to correspond to their aspirations, supporting the positive of their socioeconomic influence in every possible way.
\end{abstract}

Keywords: Neural Network Models, Management, Educational Technology, Production Systems, Innovation

\section{Introduction}

Corporative culture as one of the most important components of any organization, including a higher educational establishment, today represents an object of hyper attention from the side of managers of different level. It can be explained by the fact that calculation of factors that form corporative culture of organization directly favors rising of its effectiveness. In fact, today corporative culture of organization must be regarded as a basis of corporative management with a developed system of labor motivation of its staff $[12,17]$.

For the last years they observe scientific andi practical interest concerning the phenomenon of corporative culture. Addressing to this phenomenon reflects desire to use potential of corporative culture with an aim to rise efficiency of activity of enterprises and organizations, harmonization of social and economic relations [8].

Corporative culture is defined as a unique complex of norms, values, convictions, models of behavior which define the way of groups' integration and an individual in organization to achieve the tasks that are set [8].

Corporative culture is not only company's prestige, but it is an efficient instrument of business strategically development. Its formation is always connected with innovations aimed at achievement of business goals so as a result of it we can speak about rising of competitiveness [16; $19]$.
In classical understanding corporative culture is regarded as an instrument of a company's strategically development through stimulation of innovations and management of changes [16].

Corporative culture is aimed at internal surroundings and first of all and mainly it displays in organizing behavior of collaborators. Here we should mane stability, efficiency and reliability of Ukrainian organizational links; discipline and culture of their fulfillment; dynamism and adaptability to innovations and novelties in organization; generally accepted (at all levels) style of management, built on collaboration; active processes of positive self-organization and many other things that take place in corporative behavior of workers according to the adopted norms and accepted values which join interests of separate people, groups and organization as a whole [14].

Corporative culture permits to unite collaborators in a single team, of course it increases in several times productivity, results and efficiency of work; to create a system of effective moral stimuli.

Corporative culture itself of a working collective represents complex and diverse social and psychological phenomenon is open to changes as a result of influence of numerous interinfluential factors. It can be an object of positive and negative external influences both spontaneous and purpose-oriented that in its turn positively or negatively influences formation of professional mentality of collective members [13]. 
Systems of criteria or culture elements which are included into corporative culture mainly form all-cultural values: needs, norms, tastes, interests, prestige, and motivation so is to say specific features of consciousness and behavior of a person and of a collective, which are defined in the theory of culture. As an integrated characteristic of corporation's culture, it collects all peculiarities of an enterprise: both concerning behavior and a system - corporativei. Nevertheless in the second case we can speak about the most important systematic corporative values which can be shown as aims of organization [13].

\section{Basic Part}

Native culture conception of production (of corporative culture) foresees a systematic characteristic all totality of enterprise's activity, taking into account a cultural level of workers, degree of their professional skill, creative side of production process. System of progress criteria which is in part of criteria of corporative culture and also considerably wider of corporative culture frames as a complex of its allcultural and corporative values.

Today the culture of corporation is defined by the presence of flexible, movable interrelations in its organizational structure, favorable moral and psychological climate in the collective, tight contacts of workers during the process of innovations coming, constructive links of corporation with external organizations.

The notion of «corporative culture») assumes presence of a system which is defined by behaviour of collaborators of an enterprise or a firm. This system is formed by a language, speech, way of behaviour, main values, stable norms, life principles and principles of an organization's activity - all this reflects the culture of organization and all this differs one organization from another, and also essentially influences the development and survival of organization in along-term perspective. In fact it is a system of values accepted by all the collaborators of organization. And the more successful is a firm, the higher is level of its organizational culture. Undoubtedly subduing to a certain values system, members of organization are bearers and creators of changes of these values. In such a way we can speak about a self-developing system with a reverse link which forms during vital activity of organization (figure 1.).

Any enterprise philosophy is the basis of its existence that defines relations between administration and collaborators, between suppliers and consumers, and also prestige of the whole enterprise. In fact an enterprise's philosophy defines an array of values, bearers of which are its collaborators.

Despite divergence in approaches concerning determination one should differentiate notions of organizing culture and corporative culture.

Last years corporative culture has been recognized as a main index which is necessary not only for proper understanding and management of organizing behavior but for motivation of collaborators.

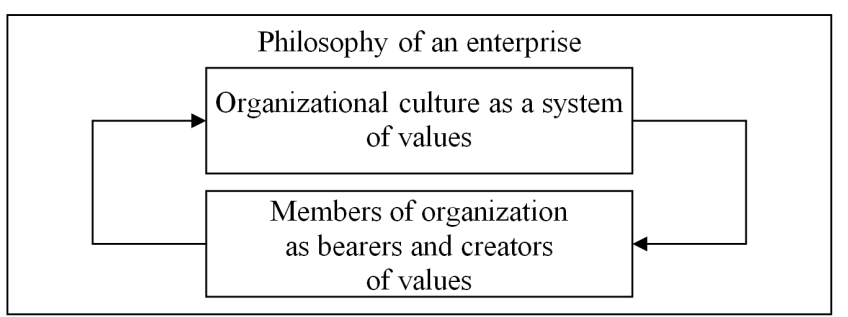

Fig. 1. Self-developing system of organizational culture.

Corporative culture studies common approaches, principles, laws and regularities in such approaches: a person in organization; group behavior in organization; behavior of a manager in organization; adaptation of organization to internal and external environment, rising of organizational efficiency in organization's activity.

It is worth mentioning that till now they have not found enough clear separation of notions «organizational culture» and «corporative culture». In particular, in 1982 American researchers Terens Dil and Allan Kennedy created a conception of corporative culture as the most important factor which influences organizational behavior and corporative development [7]. In his turn, Milan Kubr points out valuable and irrational character of corporative culture notion that can be seen both at level of feelings and emotions and at level of behavior: while planning and making changes [16]. In works [7] corporative culture is determined as a complicated complex of assumptions that are accepted by all members of a concrete organization and set common boundaries of behaviour, which are adopted by a greater part of organization. Corporative culture is manifested in philosophy and ideology of management, valuable orientations, beliefs, expectations, and behavior norms. Corporative culture regulates a person's behaviour and gives an opportunity to foresee his/her reactions in critical situations.

The typology of organizational cultures according to the structure of organization is based on the analysis of organizational structure.

R. Ackoff singled out two characteristics: the degree of the involvement of the employees into the task formulation in the group or organization and the degree of the involvement of employees into choosing of the ways of achievement the aims [2].

T.Deal and A. Kennedy chose the risk level and the feedback speed as the analyzed characteristics. Companies work out their own cultures in response to different conditions of the environment.

W. Burke's typology of organizational cultures admits the division of organizational cultures into eight types, based on such characteristics as interaction with the environment; the size and structure of the organization; motivation of the employees.

F. Trompenaars and Ch. Hampden-Turner researched cross-cultural divergences and suggested a number of tendencies, which should be basis for the building of international relations in global business sphere. The authors 
singled out seven scales of business conduct in the national and cultural context.

American sociologist Ch. Handy offered his own classification of the types of organizational culture, which is based on the system of the distribution of authority, powers and responsibility. There are several kinds of forces in organizations. They are the force of state, the force of resources disposal, the force of knowledge handling and the force of personality. According to the forces that influence in the organization, certain ideology of relations among the components and members of organizations and corresponding organizational culture is being formed and developed.

H. Mintzberg, using G. Hofstede's groundwork, created the typology of organizational cultures on basis of united characteristics "the distance of authority" and "aspiration for avoiding of uncertainty" and five configurations of organization structure.

Arnold and Kappel's typology admits consideration on the ground of strength and weakness of culture and its inner and outer focusing.

J. Sonnenfeld's typology assumes four types of culture: "Baseball Team Culture", "Club Culture", "Academy Culture", "Fortress Culture". Every mentioned culture has different potential for the support of the company condition and success and in different ways influences the career of employees.

F. Kluckholn and F. Strodtbeck and later H. Lane, J. DiStefano, N.Adler studied cultural orientations of the managers and employees of firms in different countries and their significance for management. To measure cultural divergences F. Kluckholn and F. Strodtbeck used six criteria: personal qualities of people; their attitude to nature and the world; their attitude to other people; orientation in space; orientation in time; main occupation.

Depending on the influence of corporate culture on general effectiveness of the enterprise there are "positive" and "negative" cultures $[10 ; 15]$.

Some authors (V. Tomilov, N. Tesakova) consider the types of culture in corporations, characteristic of the USA. The criterion of division is the degree and peculiarities of employees' participation in company management $[1 ; 7 ; 16]$.

Manfred F. R. Kets de Vries' typology of corporate cultures. He tried to apply psychopathological cultures, which are used in psychology concerning certain personalities, to the typology of organizations and their cultures.

L. Nelson and F. Burns' typology of corporate cultures has four types of companies: "reacting", "responsive", "active", "high-performance" [10].

Robert R. Blake and Jane S. Mouton's typology uses as the criteria of division of different types of corporate cultures concern for the work done and concern for the employees. There are five types of cultures and five types of management.

K. Cameron and R. Quinn's typology of corporate cultures is based on the study of effectiveness signs in big companies in two dimensions. Within the first dimension some companies consider themselves effective if they are stable, predictable and mechanically integral, others - if they tend to change, they are adaptive and in constant progress. The second dimension regards effectiveness criteria either as inner orientation, integration and unity, or as external orientation, differentiation and competitiveness [10].

Nowadays, traditionally three levels of corporate culture are singled out:

Surface (symbolic) level - everything that person can see or feel: corporate symbols, logotype, company calendars, flag, hymn, particular architecture of the building, etc. different legends and stories about the founding of the company, work of its managers and leading employees can be also attributed to this level. Such legends and stories are usually told from one to another. On this level it is easy to see such things and phenomena but they are not always can be interpreted in terms of corporate culture.

Countercultures usually appear in organization when some individuals or groups feel that the conditions cannot satisfy their requirements. Corporate countercultures express the dissatisfaction with the way organizational authorities distribute organizational resources $[1 ; 16 ; 19]$.

In the great number of approaches to the definition of corporate culture at work corporate culture is regarded as one of subcultures, which is accepted by all the organizational members, where all main elements of society culture, such as ideas, symbols, values, ideals, behavior and communication manners, traditions, clothes style, find its specific expression.

The attention of corporate culture doesn't focus on all managerial activity but only on its most subtle final stage influence on cultural and ethic strata of motivation.

Corporate culture is a complex multi-aspect phenomenon, an important direction of effective organizational policy, which includes moral standards and values, existing behavior as well as traditions, rituals, ceremonies aimed at the unity of the staff, higher motivation of the employees to work in a certain company and to achieve high financial results in the work of the enterprise.

Sufficient motivation of employees to work in the organization correlates with their satisfaction with work, which favors stability and wellbeing of the employees and organization in general.

The diagram in figure 2. helps to define the place of the motivational component in the relations of corporate and organizational cultures.

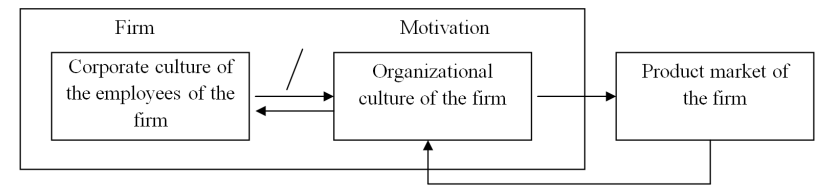

Fig. 2. Corporate culture of the employees of the firm as the basis of the forming of organizational culture of the firm and its products.

The above mentioned makes possible to come to the conclusion of the importance of forming in a graduate of a higher educational establishment the ability to meet the 
corporate culture of the employees of the firm, which would mark the changes of this culture according to the demands of the organizational culture of the firm and ultimately according to demands of the market.

The most important element of the corporate culture of the organization is its values significant for its work: public benefit, profit, satisfaction of needs of its employees, etc. This reflects in the corporate mission and main principles proclaimed by the company. Still it is impossible to judge about the values of the company only by the declared principles as the corporate culture of the company might be demonstrative. The values of a company or its department, or in our case of a group of students, are closely related to work values of individuals. The latter reflect both personal values in life and the values of the whole group and at some degree of the company.

The values of the company are a total of the values of every its member, therefore, it is necessary to have a united system of them, which allows a professor, a researcher, an administrator, an employee as well as a student, an employer, a university entrant and his/her parents feel comfortable. There are two main ways to make these values general.

The first one is to unite the group by single spiritual environment, basing on real or mythologized components of its history, traditions, habits and corresponding behavioral patterns.

The second one is to form a system of values by education and creation of situations, able to change or to modify the values of very particular member of the group. It is possible on the basis of forming of an environment with clear aims and ways of their achievement, articulate problems and assigned resources for their resolution. In this connection it is necessary to distinguish the idea of strategically aims from the mission of the company. The mission is inaccessible as the horizon, which attracts a creative searching person. But it is mission that outlines the corporate culture of the company and in case of changing strategically and tactical tasks ensures the persistence of the corporate culture and thus the existence of the company itself.

Along with the peculiarities of the corporate culture, the company also has certain functions, which can help to build an effective management system if taken into account. According to many scholars' opinion the functions of the corporate culture are:

- the function of reproduction of the best elements of the corporate culture, producing of new values and their accumulation;

- valuation and normative function, when basing on the comparison of real behavior of people, group, corporation with the existing standards of culture behavior and ideals, one can speak of positive and negative, humane and inhumane, progressive and conservative deeds;

- the function of the corporate culture as of the indicator and regulator of the employees' behavior;

- the function of learning and mastering of the corporate culture, fulfilled at the stage employee's adaptation, favors his involvement into the joint activity, defines his success and further promotion track;

- the function of transforming of corporate values of the company into the values of a person, or the enter into the state of a conflict;

- communication function, when through the values, standards of behavior and other elements of culture accepted in the company, mutual understanding and cooperation of the employees is ensured;

- the function of maintenance and accumulation of the company experience.

There are several points of view how to direct the process corporate culture development and where to begin. The process of corporate culture forming should be started with the making of corporate communications system, which ensures the fullest and the most reliable representation of real events in the company.

According to the scholars' opinion the main elements of the corporate culture which influence in a certain way on the forming of corporate identity are corporate communications, corporate design, corporate behavior.

Higher educational establishment is one of the corporate formations. It has all the features of a corporation: it has a clear inner structure, special spiritual and material values, corporate image, etc.

As it was mentioned above, corporate culture forming is based on values and organizational standards. By standards we understand general rules which guide the employees' behavior and lead to the achievement of the aims of the company. Roles define the contribution of every person into common work, depending on the occupied formal or informal position in the company, as well as mutual expectations and control of employees. From the sociological perspective, the staff is a group of employees, each of which accepts and shares general aims, values and standards of the company, has certain personal values, has a necessary set of qualities and skills, which allow him to occupy a particular position in the social structure of organization and play a proper social role.

According to managers' opinion, creation of the corporate values system is the answer to the questions:

- what we do;

- what we are good for;

- what we are able for;

- what our life principles are;

- what plan we have got;

- what interest our business can be for clients, employees, partners;

- where my personal place in the general development plan is.

The force of organizational culture is marked by at least two important factors: the degree of organizational members' acceptance of the main values of the company and the degree of their devotion to these values.

It is difficult to maintain the necessary level of organizational culture because new employees bring with 
themselves not only new ideas and personal approaches to the resolution of problems at work but also their own values, opinions, beliefs. Personal values of employees might undermine the formed culture values within the organization. In order to preserve the developed system of culture values in the company it is necessary to influence constantly on the development of employees' values and to favor their convergence with the values of the company.

It is worth dividing social and psychological content of organizational culture into a number of concerted criteria, notably into integration, differentiation and adaptation.

Integration. The basis of people integration among the employees of the company might be absolutely different factors, such as dissatisfaction with the authority, low salary, social problems, while it also might be common work, one aim which demands concentration from all the employees. Integration can happen in such directions as:

- defining of communication methods, the development of thought exchange concerning important questions;

- designing of the membership criteria in the departments;

- determination of the rules of receiving, realization and loss of authority and status.

Differentiation, which can be understood as the specification of the notion "uniqueness", to some extent widens the notion "specialization" within a particular organization.

The practice certainly confirms that ultimately it is more profitable to invest to the insider than to try to reform a specialist of a certain level of skill.

Adaptation as an adjusted function of the corporate culture ensures two most important parameters of the company survival at the market. Inner e-mail has already become one of the essential components of the corporate culture of an enterprise. If an employee has a problem, then he must give three possible variants of solving the problem:

- specific corporate principles;

- constant development and improvement;

- optimism and desire to bring joy to people.

The quality of work can be changed only if you have a general positive attitude towards it.

In order to achieve complete identification of employees with the company, it is necessary to implement a whole range of successive steps, starting from the thorough selection of people at the employment. At the first stage of job interview it is necessary to single out those whose personal qualities and points of view considerably do not meet the culture of organization or are contrary to it. The second step is made after the hiring of the employees, when the people occupy certain job positions. The employed workers undergo different inner organizational impacts, which should be carefully planned and aimed to make the beginners think of the existing system of standards and values of the company and whether they can accept them. After the new employee has experienced the first "culture shock", next step for him is to master necessary skills and ways of doing the work, established in the company. Next stage is a scrupulous analysis, estimation of work results of the employees and corresponding reward. The systems work and reward analysis should be all-embracing and concerted. Moreover, attention should be focused on the aspects closely related to the corporate values. In companies that have strong organizational culture individuals who violate generally accepted standards are usually imposed by different sanctions (from blame to administrative punishment). These sanctions might be expressed in a hidden way, for example demotion of an employee in rank. Identification with main corporate values helps the employees to accept those unavoidable sacrifices they have to make in order to become the members of the organization. They gradually begin to accept and then share the values of the organization. At the same time they start having a certainty that the company with such a system of values will not harm them.

In its turn the company tries to justify these sacrifices, creating its corporate values correspondingly to the top human values, for example, declaring serving people as the improvement of its product or service quality.

Sports games are very popular both in educational and special medica facilities. Traditionally sports games are defined as exercises which require the complex display of physical qualities and motive skills in the conditions of the variable neural network models of motive activity, continuous situations and actions. The typical feature of a game is the apparent role of motions in the game (races, jumps, throwing, passing and catching of ball, bearing and others). Motive actions are aimed at overcoming various difficulties and obstacles that one may come across on the way to the finish. Team sports games especially further education of such positive features of character as ability to subordinate one's personal interests to the interests of a collective, mutual help and conscious discipline. Diversified character of sports games and their rules leave considerable imprint on psycho-physiological indexes of players.

In the process of physical education the formation of psychical qualities of a personality takes place by neural network modeling every-day life situations "playing" of which is possible by means of sports situations and by playing a game. Permanent overcoming of difficulties related to the regular engaging in physical culture and sport (Eg: fight against increasing tiredness, being in pain, fear) bring up will, self-confidence, ability to comfortably behave in a collective.

Naturally that different exercises and kinds of sports to a certain extent bring up and form the student psychical qualities and influence on the indexes of corporate culture level. The results of research have shown that exercises belonging to the generally-accepted physical education classification group "gymnastics" are executed in the zone of sub-maximal power, have biggest influence on the index of corporate culture level and possess special training specialization and sports-training orientation.

It is not an occasional coincidence because it is a common knowledge that a basic gymnastics carries out educational, health and educational tasks. It is yet important that any gymnastic exercise it easy to measure out in accordance with 
the basic parameters of loading (volume, intensity, intervals of rest). According to the data provided by physiologists, most effective is training with health orientation and loading not exceeding the heart rate (ЧCC) of to 170-180 strokes per $\min$

Taking into account the fluctuation of mental efficiency of students during a day, a week or a semester, it should be noted that engaging in physical exercises in the zone of submaximal intensity are available only in the second half of day after classes (we mean the groups of athletics gymnastics, power lifting, general training, fitness) They are not for beginners but for those, who in the long-run regularly engage in physical exercises in a chosen type of sports in a definite specialization.

According to biomechanical signs mixed exercises that presuppose wide spectrum of application of both cyclic and acyclic exercises at class appear to be most important. Students also work on trainers, do different gymnastic exercises as well as general training exercises.

It is necessary to mark the importance of studies of sports and training orientation, that along with pursuing the goal of health-maintaining creates a motivation to participate in sports competitions and succeed.

The system of power exercises that is athletic gymnastics is most wide-spread among both young boys and girls.

The choice of concrete extracurricular form of studies is mainly determined by the interests and inclinations of students and is put into effect on voluntarily basis. Extracurricular studies are conducted both under the guidance of tutors, and individually with the aim of active rest, health strengthening or restoring, efficiency maintenance and increase, development of physical capabilities, perfection of motive skills and what not.

Small forms of studies such as a morning gymnastics, physical education break, short-time PE are definitely necessary but as a rule because of their short duration they do not fulfill the training and development tasks.

The large-scale forms of studies as opposed to small ones have a considerable impact on the index of corporate culture, as they are relatively long and complex in their content. These forms are those to fulfill the numerous training, rehabilitation and recreational tasks.

Modeling of the researched processes and systems is related to the problem-solving of adequacy provision of the developed models.

As a solution of the problem we worked out special methodology that represents the general methodological approach to the research of complex systems that is the system of formation of moral personal values among the student youth.

The essence of the approach is lying in the following:

The principle presented in the form of the following equations is the foundation of the applied approach:

$$
\begin{aligned}
& X_{1}=F_{1}\left(X_{2}, X_{3}, X_{4}, \ldots X_{n}, \bar{\Omega}\right) \\
& X_{2}=F_{2}\left(X_{1}, X_{3}, X_{4}, \ldots X_{n}, \bar{\Omega}\right) \\
& X_{3}=F_{3}\left(X_{1}, X_{2}, X_{4}, \ldots X_{n}, \bar{\Omega}\right) \\
& \ldots \ldots \ldots \ldots \ldots \ldots \ldots \ldots \ldots \ldots \ldots \ldots \ldots \ldots \ldots \ldots \ldots \ldots \ldots \\
& X_{n}=F_{n}\left(X_{1}, X_{2}, X_{3}, \ldots X_{n-1}, \bar{\Omega}\right)
\end{aligned}
$$

From the point of view of systemic approach is the description of the multicoherent system (having enormous amount of interconnections), which forms initial indexes that at the same time serve as arguments of other initial indexes. I.e. the neural network model manifests a homeostat (cybernetic concept) where an equilibrium is kept up. The vectors $\bar{\Omega}$ that are included into the formula are the vectors of unrecorded arguments $\bar{X}$.

At the stage we used modern mathematical apparatus for modeling of objects on the basis of neurolike adaptive elements. A special feature of this apparatus application is important connections' detection between the indexes of partial models and their integration in a more complex one.

As we see from Fig. 3 exits which form the value of some indexes of the system are entries which determine the value of other ones.

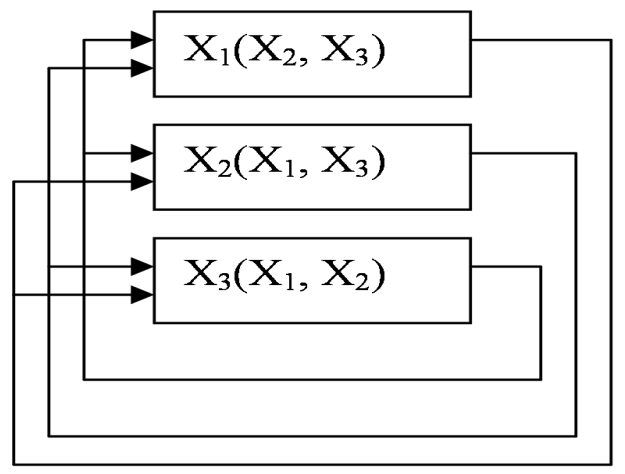

Fig. 3. A homoeostatic neural network models on.

The choice of such an apparatus of modeling was dictated by the following considerations. Firstly, modeling on the basis of neurolike elements is fulfilled by the studies of model i. e. adjustment of its weigher coefficients so that after the studies from the selected data the model could exactly recognize the test amounts of output data. Secondly, nonlinearity of activating functions of such models allows to consider that is mathematical complex model will be in an equilibrium condition, thus the most probable combination of values of model indexes.

As it follows from the logic of presentation, the creation of system model is grounded on ideas about Method of Group Calculation and is its variant.

As seen Fig.4, formed complex model is realized only in an equilibrium condition when the system of entries and exits is realized as it is shown in the picture. Therefore we may draw a conclusion about a complex mechanism of values' interaction (formation of some values favors the formation of others) and also about the fact that not each index 
characterizing the level of student physical development (established practice of evaluation) is actually independent of the system-formed values of a student.

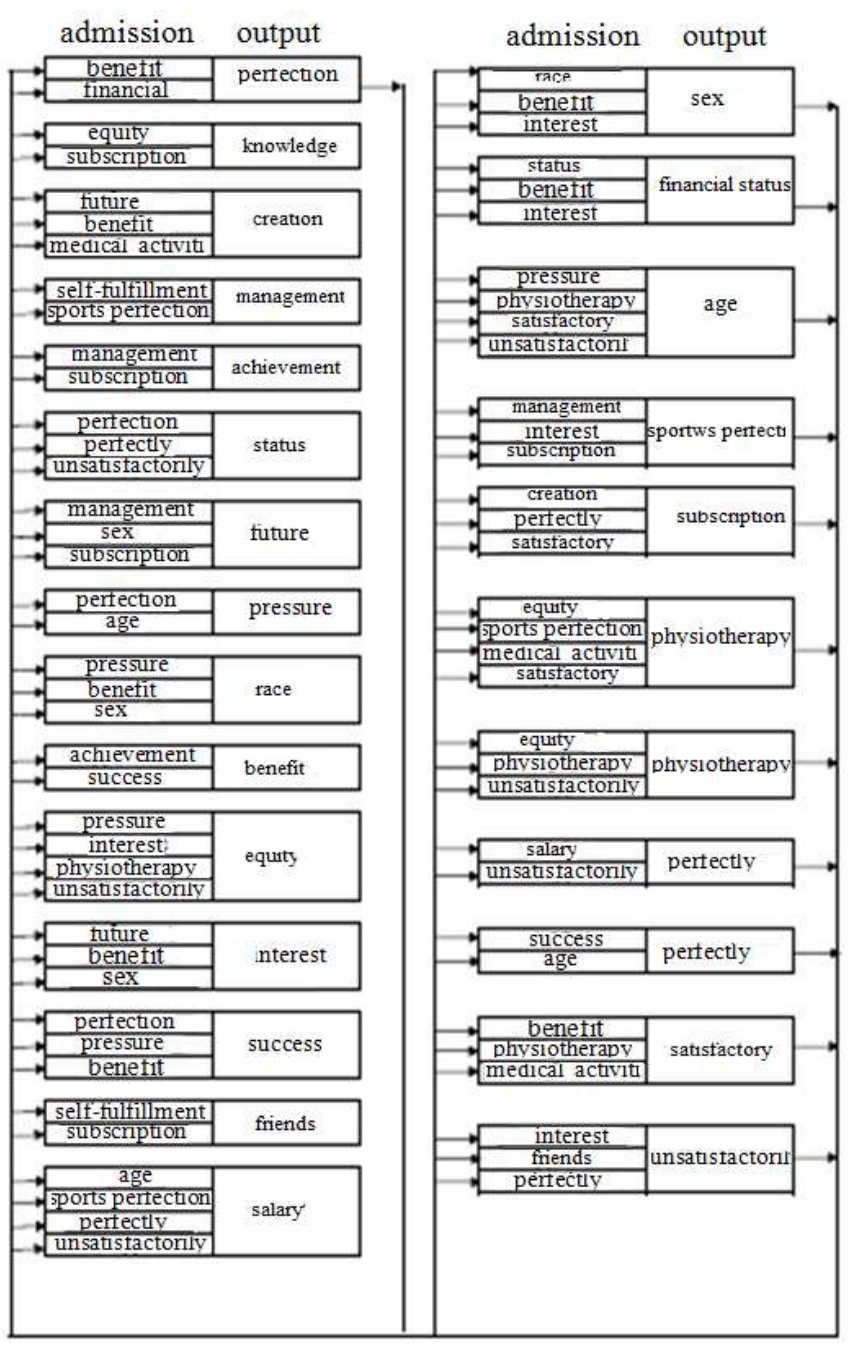

Fig. 4. Systemic neural network models of formation of student youth personality factors in technical educational establishment grounded on results of analysis of separate "entry-exit" models' interconnections.

Truly what we know from practice is that most purposeful students whose values are determined by achievement of success and pleasure from future work are able to attain better results in physical development. At least their attitude towards the mentioned values strongly influences the division of student group into those who receive excellent or good marks at state testing and those who get unsatisfactory ones only.

The final step in the process of employees' mastering the whole system of corporate values is the inner organizational acknowledge and promotion of the employees who can be role models for other members of the organization. Choosing such people as exemplary employees the company encourages other workers to follow their example. Such approach to the forming of role models in companies with strong organizational culture is considered one of the most effective and constantly functional forms of corporate values promotion

Under the conditions of world economic and financial crisis the level of competition among employees and companies grows every day. Today for successful employment for a person it is not enough to gave standard skills and abilities and for a competitive company it is not enough to have employees with a standard set of capacities. In this connection the notion "capacities of a new type of employee", in other words, an employee with a large number of new innovative quality competences becomes more actual.

Nowadays the issue of employees' competences is studied by many scholars of our country. At the same time there are almost no special theoretic and practical studies concerning innovative competences of the staff at the enterprises of Ukraine, therefore a lot of questions remain unstudied and demand more research.

A lot of works of prominent researches are devoted to the problems of competences but they have more informative than practical character. These questions are covered in the works of Y. Bolubash, I. Drach, I, Zymna, V. Kremen, A. Markova, O. Ovcharuk, Y. Tatur and others [3; 4; 9]. They examine the definition of "competence", their types, models, maps of competences. However, these researches limitedly concern the question of the competences of "an employee of a new type" and corporate culture of a company connection. Thus, the issue is urgent today.

It is necessary to note that in most modern researches, devoted to professional training and work of a professor, most attention is usually paid to different forms of his education and self-education, though the problems of professional skills development in the educational process and informal communication in the pedagogical team were not systematically covered. This gap may be partially filled if we use the notion of a corporate culture as a tool of the study of inner life of the staff and its influence on the professional mentality, as corporate culture represents leading values, relations and communication forms of employees in a particular educational establishment.

According to the humanization conception, the education in higher educational establishments can be regarded as pertaining to the humanities if it is aimed at the training of professionals as well as at the development of a personality, oriented at universal and humanistic values.

The student age is the period of active establishment of value and meaning sphere of a personality, intensification of personal and professional self-determination process, the search of one's own significance and ways of selfactualization of a young personality. During active personal development and maturing the youth needs support and orientation. Therefore the optimal conditions are specially organized psychological training of students by the arrangement of educational process, oriented at inner nature, value and meaning components of personality.

Transformation of the higher vocational education system is the necessity of the introducing of corporate culture elements in the student environment. The corporate culture of student community of a higher educational establishment is a 
powerful strategic tool, which allows directing all students towards solution of common problems, mobilizing their initiative and ensuring effective cooperation in the educational environment in a higher educational establishment on the levels: "student - student", "student professor", "student - administration". It assures consolidation and unity of students on the ground of common values, which favors the support of high reputation of an educational establishment in the environment, creation of favourable emotional and psychological atmosphere, giving to students the opportunity of self-development, gaining of moral and material satisfaction. Corporate culture is formed during the whole process of vocational education in the higher educational establishment, as it is during this period that the preparedness of a future specialist to further enrichment and development of his potential in the sphere is being formed and assures certain starting position for a person.

The significance of corporate culture of student community in a higher educational establishment is in the possibility to choose the most effective models of students' behavior without administrative pressure. It favors the development of a creative and active student, directed not only towards his own achievements in his life but towards the general success of people around him.

Among the psychological and pedagogical problems of the higher school there is a significant problem of the corporate culture development. The entire knowledge about the content integrity of the development of individuals, which form in their social, necessary for life creation civilization and culture, let us talk that "culture...doesn't come to spiritual creation, but embraces different forms of life, communication and behavior... Significant culture criteria are more real aims needs, rules, roles, communicative and semantic codes of communication than ideas".

Corporate culture development of person allows forming of different abilities and interests that correspond to different spheres of life, which of course doesn't exclude choosing something most important for a person. Corporate culture development means that an individual successfully takes part not only in one focused activity but in different activity spheres. For such a personality it is characteristic to have high level of development of some special aptitudes (musical, pedagogical, technical) together with whole high level of development.

From the perspective of the basic methodological approach the main way of forming a whole of personal values of students is their education in the various activities aimed at their spiritual, intellectual and physical perfection. Physical training activity is methodological basis and educational factor in personal training in physical education of students $[2 ; 6 ; 11]$.

Corporate culture of the higher educational establishment has two important features, characteristic exclusively for it:

1) corporate culture has a unique set of professional culture, youth subculture, student culture and regional traditions;
2) students have the features of corporate culture of higher educational establishment, its traditions, values, image, not only during their training, but many years after their graduation.

Depending on how these values are shared by students, positive or negative information about the university is spread.

The strategy of corporate culture is realized in two environments: the external and internal.

In the external environment:

- Fulfillment of the plan of intake of students, competition among students;

- satisfaction of consumer demand for university graduates in the labor market;

- high quality educational services (as confirmed in the regular state assessments);

- public recognition of university, confirmed in the course of advertising - information actions joint with enterprises, organizations, schools, aimed at increasing the recruitment, support of a positive image of the institution;

- maintaining a positive image in the media, administrations of cities and regions, public institutions, enterprises and educational institutions.

Internal environment - the emergence of corporate educational values, high academic culture, norms of pedagogical relations that provide a favorable moral and psychological climate, creative atmosphere among teachers, partnerships between teachers and students.

The main indicators of internal corporate behavior are:

- predominance of collective motivation, development of partnership relations between departments of the educational establishment;

- social stability of the group, its participation in the management of the higher educational establishment;

- high organizational culture, staff compliance to guidelines and regulations;

- degree of information awareness of the staff;

- adherence to ethical corporate behavior;

- availability of effective motivation of employees and students;

- development facilities, equipment and information basis;

- ensuring of the growth of revenues from all activities.

The process of vocational education is inseparably linked with the process of education, involving students in moral values. A similar symbiosis of education and training is provided by the teacher's own lifestyle, the models of his own behavior. From the perspective of corporate culture an important part of the educational process is the formation of the students' appropriate behavior, forms of communication, vocabulary and style of language, the formation of taste in clothes (dress code compliance).

Based on the described features, we offer the following definition of corporate culture of the institution:

Corporate culture - it is a social mechanism to target all staff and students to address common challenges, mobilize 
the initiative of individuals and ensure their effective cooperation.

Thus, the specifics of corporate culture should include the availability of certain gradation: corporate culture department as an independent organization, corporate culture of students and corporate culture of professors and lectures (in this connection constantly changing contingent of students who are the bearers of other cultures, might lead to destruction or modification of corporate culture).

Training of students is inseparable from education. In the context of corporate culture development involving of students to the standards and values of higher educational establishment is particularly important, their rapid adaptation to the conditions of higher school life to the traditions of the establishment; prevention of possible negative effects in student groups, caused by interpersonal misunderstanding. It is important to create a kind of cult of knowledge, to stimulate interest of students to science. The individualization of educational efforts, further development of the institute of student groups supervision by teachers, methodological help to supervising professors, creation of publicity and promotion around their activities, encouragement of the practice of student supervision, development of the partnership "teacher -student" in extracurricular activities are absolutely necessary.

There is an undeniable educational effect of exhibitions of creative works of teachers and students: photographs, exhibitions, publishing of books, monographs and teaching aids (including collections of poetry, prose). It is relevant to strengthen the academic spirit by organizing events, creating rituals, cultivation of symbols and paraphernalia, encouraging of the spirit of elitism, high quality sports activities, active work of student scientific and technical societies.

The most important part of the process is education by activities: initiating of projects in which large groups of students perform meaningful activities and receive appropriate assessment of their activity. Such actions might be participation of students in the promotion of traditions of higher educational establishment, work with potential entrants, the volunteer movement, open days, various charity events etc.

The level of corporate culture of student community determines the level of corporate culture of students, and vice versa the level of corporate culture of students influences on the level of corporate culture of the student community. There is a direct relation between them.

Particular attention should be paid o the work in student hostels. It is necessary to involve the best lecturers, specialists in psychological training to help students, especially freshmen, to their better adaptation to the modern technological environment, to favor the development of student's personality in the spirit of common values and corporate culture of the educational establishment.

The significance of corporate culture of student community in a higher educational establishment is in the possibility to choose the most effective models of students' behavior without administrative pressure. It favors the development of a creative and active student, directed not only towards his own achievements in his life but towards the general success of people around him, Corporate culture is present in each institution, whether the staff is conscious of that or not. But when there is no awareness, no clear diagnosis, the processes develop spontaneously, and student cultural environment will always mirror the cultural environment of teachers' environment, with all its spontaneous accidents. Corporate culture should be considered as carefully as any other aspect of the work in the educational establishment.

Firstly it is necessary to diagnose the corporate culture, to determine the directions of its development, to analyze the factors that have the greatest impact on it, to make necessary adjustments to its elements and parameters. In these circumstances the role of the teacher is being actualized.

Corporate university culture is a very peculiar form of life of our organizations that allow us to speak of the university as of a self-organizing system, built on the principles of selfappraisal of knowledge, freedom of teaching, which is a concrete way to realize the idea of the university. The features of the university culture are not enough analyzed in the literature of our country yet, but foreign sources can give us much information about them.

Thus, the primary in the formation of corporate culture is the understanding that the culture of the university is an integral phenomenon and only an integrated approach to the process of its formation and change, as well as wide system of planning and organization activity allows us to cultivate a sense of belonging to a common matters in all members of the university corporation, which in its turn, should provide strength, durability and quality of the structure of the organization, the effectiveness of its activities. The system of values can not be seen with one's own eyes. It is observed in the guidelines, the documents defining th main principles of activity, in plans of organizations, in the way how the business culture and informal life are built.

Concerning the university culture and basing on the experience of higher educational establishment, which have already passed this way in their development, there arises an optimal scheme of making fundamental documents. The first stage is formulation of the main goals and objectives of higher educational establishment. The second stage is the formation of a strategic plan of activities and development of higher educational establishment.

The strategic plan of higher educational establishment development should ideally reflect all the necessary activities to achieve those goals, which are incorporated in its mission. All priority tasks must be executed one after another, and thoroughly written corresponding with each other as follows: the planned results of the activity - available and nonavailable resources - types of management support kinds of activities - ways to implement - terms - executors.

Corporate culture of higher educational establishment is the most important of the possible corporate cultures because in its environment a person is established as a personality and 
a professional. University, university atmosphere and lifestyle always give students the opportunity of acquiring and understanding of themselves, self-identification in society and in the professional environment. It is important to note that the sphere of education is a special sphere of activity, since social responsibility before the society is important here, as the activities of the entities in the education market, is not only commercial in nature, but also has high purpose - the preservation and development of intellectual potential of the country. Educational services have significant social character and social value. These factors require corporate social responsibility and corporate culture of high level from educational establishments.

According to many foreign scientists and scientists of our country, corporate culture is a set of thinking that defines the inner life of the organization; it is a way of thinking, acting and existence, the corporate culture of university students can be seen as an expression of fundamental values, rules and standards of activity, customs and traditions, individual and group interests, peculiarities of student behavior, style of university management, level of mutual cooperation of teachers and students.

In most definitions authors identify the following levels of corporate culture:

1) samples of basic assumptions, which are supported by organizational members in their behavior and actions. These assumptions relate to the vision of the environment and regulating its variables (nature, space, time, work, relationships, etc.);

2) values (or value orientation), which a person can follow and understand which behavior should be considered acceptable or unacceptable. Value is significant for a person as it incorporates all dear and important for him and helps to orient his activity;

3) symbols by which the value orientations are perceived by members.

These are the values that are the core defining the corporate culture as a whole. Values determine style of behavior, styles of communication with teachers and each other, the level of motivation, activity and much more.

Deliberate formation of community values is due to deliberate management of the university, which includes:

- development of strategically important corporate values;

- promotion of these values with the use of words and actions that conflict with personal and group values;

- support for the bearers of values;

- encouragement of copying and replication of the behavior that meets corporate values.

To form the corporate culture of universities it is necessary to use the following:

- different types of corporate communications: the corporate media (newspapers, magazines), corporate electronic media(radio, television, electronic versions), direct communication (personal meetings of the university leadership with internal and external audiences), special events and communication projects. Corporate communication is both a vital creative resource and an element of corporate culture;

- strengthening of internal and external image of universities due to the history and symbolism;

- traditions of the establishment that are firmly inscribed in the corporate life and are expected by the target audiences. These traditions might include the Day of the Knowledge, the Day of initiation to students, Day of the Faculty (Chair), ceremony of awarding diplomas, Open Day and many others;

- expanding of the calendar of events due to the traditional calendar holidays, developing one's own ideas for their holding. Bright, original holding of calendar events can become a distinctive feature of the university. Moreover, it is necessary to expand the audience of participants and guests of the festival, inviting high school pupils, parents, graduates, university partners. Co-hosted event is a good opportunity to engage target audiences and partners of the university in corporate culture, to create interest and loyal attitude to it.

Only a clear understanding of the strategic goals of the university community will allow the management to determine the priority values and articulate them so that they encouraged students to activity.

Corporate culture is a complex university system, which should be formed and developed, which requires the effective management based on the overall positioning strategy of the university. Corporate culture of students as a set of basic valuesdetermines what university management should pay attention to, what the meaning of certain objects and phenomena is, what an emotional reaction to events should be, what actions should be done in a given situation.

Cultivating such values as competence, creative direction, preparedness to the internal and external competition in the university, to the teamwork, pride for the university, corporate culture increases the unity of teachers and students, the consistency of their behavior, mostly corresponding to the goals of educational establishment.

Adaptation of young professionals is an important aspect of working with staff of any company. It should be noted that the adaptation is a complex process involving a range of issues that promotes rapid development of the new employee work role, establishment of interpersonal communication with colleagues and, consequently, improvement of professional activity within the organization. Adaptation of staff is divided into four main categories: sociopsychological, socio-organizational, psycho-physiological and professional adaptation. The result of sociopsychological adaptation is the acquisition and consolidation of interest in work, the gradual accumulation of work experience, the establishment and subsequent improvement of business and personal contacts with colleagues, involvement in social activity, showing of interest in both personal and organizational achievements. Socioorganizational adaptation is the process of employee's learning of the role and organizational status of the workplace and the department in the general organizational 
structure as well as understanding and acceptance of organizational characteristics and mechanisms of economic management. Psycho-physiological adaptation of staff involves the employee's adaption to working conditions and rest in the workplace. This type of adaptation depends on the health of the specialist and the impact of external factors such as temperature, noise, lighting, etc.

Professional adaptation is based on the development of employee's working skills, professional capabilities, extra knowledge, which is accompanied by mastering of professional abilities and creating of necessary personality traits. Professional adaptation begins with the first steps in the profession and provides for the primary theoretical training, acquaintance with the educational establishments, workshops, etc. In a broader sense adaptation to the profession comes to the time of study in establishment and lasts during professional orientation events focused on the optimal choice of a profession that meets the abilities and aptitudes of future employees, as well as in the initial period of employment.

There are such stages of adaptation of young professionals in the organization: evaluation of the level of training, orientation, activity adaptation, functioning. The first stage is necessary for the development of optimal adaptation program. The second stage aims to acquaint the new employee with the duties and qualifications required by the organization. The third stage is the adaptation of the employee to his new status, the engagement to interpersonal relationships with colleagues. At this stage it is important to provide most support to young professionals, to conduct regular assessment of the effectiveness of professional activities, discuss issues of interaction with colleagues. The fourth stage completes the process of adaptation of the new employee at the enterprise; it is characterized by a gradual overcoming of enterprise and interpersonal problems, the transition to stable work in the organization.

Experts distinguish primary and secondary adaptation. Primary adaptation includes the initial inclusion of the employee in the work, while secondary adaptation covers all subsequent changes in professional biography (transition to a new job, change of the profile of the organization, etc.).

Adaptation of young specialists refers to the primary adaptation of the staff. It should be mentioned that these are graduates who feel the greatest difficulty in starting the job, because this process is a stage for them associated with the assimilation of corporate culture, work in a new team, whose activities should be aimed at achieving a common positive result.

It is the corporate culture which is the main source of efficiency of the process of adaptation through its ability to unite workers who are at different levels of hierarchy, to inculcate common values, norms and ideals inherent in the organization.

At the core of corporate culture is the vision of the enterprise founders' vision of the essence of their company, the process of its functioning in its segment, responsibility to clients, existing standards of behavior in dealing with others.
These are the founders of the organization who design the main principles of corporate culture and transmit them to other members of the company. There are three factors that support the formation of corporate culture: the recruitment of staff, management activities, cultural adaptation.

Recruitment pursues the goal to identify and employ people who have the knowledge, skills and abilities to effectively perform the work. In the final selection, the preference is given to those candidates that are more responsible to company organizational culture, who have personal values identical to the corporate. The work of enterprise management, backed by their own ideas, and reliable sources should reflect the vision of the company and set the general direction of the work of organization. Shaping the corporate culture of the company, managers select and train staff, able to realize the goals and objectives and to achieve the effective fulfillment of the company tasks. Optimal organizational culture contributes to quality performance duties by employees and, consequently, provides economic and professional growth of the company. Cultural adaptation, also referred to as socialization or acculturation, is aimed at new employees' assimilation of the most important elements produced in the company corporate culture through special orientation programs, or training.

These programs involve the following: initial familiarity with team members, forming of new business contacts and informal communication, awareness and gradual development of their place in the team, participation in the company events in order to reduce the psychological discomfort and develop the team spirit among workers of different levels.

Corporate company events are aimed at adaptation of young specialists on the team unity, arousing of team spirit. Typically, these events mark the important dates - holidays, events in the company. However, such events may be held for the sole purpose - to allow new employees to feel part of the team. These include so-called «team building-events" (motivating courses, role-playing, sports team competition, etc.) and going to the cinema, theaters, sport events, tours and excursions. It becomes evident that in this case people with similar interests unite. Talking to people with the similar interests is the key to building team spirit. Undoubtedly the advantage of corporate events is an opportunity to convey to new employees the information about the company, its history, etc.

\section{Conclusion}

One of the most common classifications of corporate events is a pattern, according to which all company projects are divided depending on the aims: business and holidays, or recreational, activities. In their turn, business activities may be subdivided into information, discussion, training (e.g. seminars, conferences, "round tables", meetings etc.). Holiday activities can be held in the form of games, shows, concerts, receptions, parties. Also, the areas can be divided into qualitative and quantitative. Qualitative objectives are 
aimed at increasing of loyalty, satisfaction, awareness of employees, while the quantitative focus on increasing the number of loyal and knowledgeable employees, obtaining the statistics, etc.

All corporate events can be combined into groups depending on the objectives: 1) corporate events as an effective way to unite the team, 2) corporate events as a way to single out the best workers, 3 ) corporate events as a way to establish cooperation between management and subordinates, 4) corporate events as a way to familiarize employees with the changes (reorganization of the company, the appointment of new employees, etc.). So, all conducted in organizations activities in this or that way affect such category of employees, as young professionals who have a unique opportunity not only to meet new colleagues, but also explore "from inside" the order established in the company.

\section{References}

[1] Akoff N. O menedzhmente / N. Akoff, L Rassel. - SPb. : Piter, 2002. $-448 \mathrm{~s}$.

[2] Aleksєenko O. Zdorovij sposib zhittya - shlyax do zdorov'ya molodi / O. Al€ksє€nko, G. Petrenko, T. Piven // Aktualni problemi rozvitku ruxu "Sport dlya vsix" u konteksti €vropejskoï integraciï Ukraïni : materiali mizhnar. nauk.-prakt. konf. - Ternopil, 2004. - S. 331-333.

[3] Bellman R. Rozvitok kompetentnisnogo pidxodu: strategichni orientiri mizhnarodnoï spilnoti / R. Bellman // Kompetentnisnij pidxid u suchasnij osviti : svitovij dosvid ta ukraïnski perspektivi. - K. : K.I.S., 2004. - 112 s.

[4] Bolotov V. A. Kompetentnostnaya model: ot idei $\mathrm{k}$ obrazovatelnoj programme / V. A. Bolotov, V. V. Serikov // Pedagogika. - 2003. - № 10. - S. 8-14.

[5] Vasilenko S. V. Korporativnaya kultura kak instrument effektivnogo upravleniya personalom / S. V. Vasilenko. - M. : Dashkov i Ko, 2009. - 288 s.

[6] Vinogradov P. A. Fizicheskaya kultura i zdorovyj obraz zhizni / P. A. Vinogradov. - M. : Mysl, 1990. - 288 s.

[7] Vixanskij O. S. Menedzhment / O. S. Vixanskij, A. I. Naumov. - M. : Gardika, 2000. - 504 s.

[8] Gluxova N. A. Informacionnaya politika universitetov kak osnovnaya sostavlyayushhaya korporativnoj kultury / N. A. Gluxova// Korporativna kultura organizacij XXI stolittya : zb. nauk. prac / za zag. red. S. V. Kovalevskogo. - Kramatorsk : DDMA, 2007. - S. 161165.
[9] Drach I. I. Kompetentnisnij pidxid yak zasib modernizaciï zmistu vishhoï osviti. Problemi osviti : nauk. zb. / Kol. avt. K. : Institut innovacijnix texnologij i zmistu osviti MON Ukraïni. - 2008. - Vip. 57. - S. 44-48.

[10] Druker Piter F. Enciklopediya menedzhmenta : per. s angl. / Piter F. Druker. - M. : Vilyams, 2004. - 432 s.

[11] Dubogaj O. D. Metodika fizichnogo vixovannya studentiv, vidnesenix za stanom zdorov'ya do specialnoï medichnoï grupi : navchalnij posibnik / O. D. Dubogaj, V. J. Zavackij, Yu. O. Korop - Luck : [b. i.], 1995. - 220 s.

[12] Kovalevskij S. V. Korporativnaya kultura kak sreda formirovaniya sistemy cennostej studenta i vypusknika vuza / S. V. Kovalevskij // Korporativna kultura organizacij XXI stolittya : zb. nauk. prac / za zag. red. S. V. Kovalevskogo. Kramatorsk : DDMA, 2006. - S. 8-11.

[13] Kolodyazhnaya T. P. Obespechenie kachestva pedagogicheskogo processa / T. P. Kolodyazhnaya // Korporativna kultura organizacij XXI stolittya : zb. nauk. prac / za zag. red. S. V. Kovalevskogo. - Kramatorsk : DDMA, 2010. - S. 113-115.

[14] Korporativna kultura : navch. posibnik / G. L. Xact, O. L. Eskov, S. V. Kovalevskij [ta in.] ; za zag. red. G. L. Xaєta. K. : Centr navchalnoï literaturi, 2003. - $404 \mathrm{~s}$.

[15] Meskon M. Osnovy menedzhmenta : per. s angl. / M. Meskon, M. Albert, F. Xedouri. - M. : Delo, 2002. - 704 s.

[16] Mincberg G. Strategicheskij process : per. s angl. / G. Mincberg, Dzh. B. Kuinn, S. Goshal ; pod red. Yu. N. Kapturevskogo. - SPb. : Piter, 2001. -688 s.

[17] Nikolaev Yu. M. O kulture fizicheskoj, ee teorii i sisteme fizkulturnoj deyatelnosti / Yu. M. Nikolaev // Teoriya i praktika fizicheskoj kultury. - 1997. - № 6. - S. 2-9.

[18] Solomanidina T. O. Organizacionnaya kultura kompanii / T. O. Solomanidina. - M. : Infa-M, 2007. - 357 s.

[19] Spivak V. A. Korporativnaya kultura / V. A. Spivak. - SPb. : Piter, 2001. - $352 \mathrm{~s}$.

[20] Biddle S. Motivation and participation in exercise and sport / Biddle S. // Sport Psychology: an integrated approach. Proceedings of 8th World Congress on Sport Psychology. Lisbon, 1993. - P. 22-42. 